\title{
A Philosophical Introduction of Islamic Political System and Social Behavior
}

\author{
Abdulaziz Omar A. Jughaiman, \\ King Saud University, Saudi Arabia
}

Doi:10.19044/esj.2019.v15n26p89 ～URL:http://dx.doi.org/10.19044/esj.2019.v15n26p89

\begin{abstract}
This paper focuses on exploring Islamic social behavior and Islamic political system nature as a religion from a scientific and philosophical perspective and the most important Islamic aims in politics and society. It also aims to explore the phenomenon, true concepts, and the concepts of its ideology in addition to suggesting various definitions. This paper used a logical analysis method, philosophical interpretations, and verses of the Holy Quran without subjecting it to a specific interpretation. It also used measurement and deduction method, and it compares different political systems and different social structures, in Islamic and non-Islamic country, based on common factors and special Islamic factors. This present paper shows that Muslim community behavior is subjected to religious orientation and the state law. This paper found that Islam calls for peace and accepts modern political concepts. Islamic country should accept the concept of party rather than the concept of group. Also, Islam calls for a social behavior that respects privacy by forbidding spying and criticizing an individual within the scope of his personal life. This paper found that entry into Islam is optional, while getting out of Islam is not optional. This paper also diagnoses the civilization clash and how to avoid it. Therefore, this paper hereby suggests the explanations and definitions of many important phenomenon and concepts, which would contribute to a better understanding of many phenomena in the religion, ethic, law, society, and politics for better decision-making.
\end{abstract}

Keywords: Philosophy, Religion, Rights, International Law, Society, Politics, Decision-making

\section{Introduction}

Islam is a message sent by a prophet who is not versed in reading, writing, poetry, or science and, at the same time, with the Holy Quran as a linguistic miracle. The main role of Islam is to refute many fabrication stories about the prophet. This message is taking a civilian and peaceful beginning 
with main the objective of legislation and justice seeking. This in turn results in suffering by persecution, which forced them to migrate from place to place. Nevertheless, this message spreads until it developed and created the so-called Islamic civilization that stretched across centuries. Islam has created a social revolution and political transformation, and it has initiated a state with a new concept. However, the application of the principles of Islam varied across centuries from state to state.

The states which applied secularism or sharia were reputable due to their method of application and ethical commitment.

"Social and political philosophy involves the building of the state and society, its functions and meanings. Man is seen as a social being who achieves his whole existence within the community. In our time, this philosophy deals with the criticism that is directed to the conditions of life in modern industrial societies. The philosophy of history tries to grasp the essence of history, its meaning and its procession; also, this philosophy attempts to interpret the history and to understand man in his historical procession" (Peter Kunzmann, Franz-Peter Burkard, Franz Wiedmann, Axel Weib, \& George Katorah, 1991).

\section{Political and Social Behavior}

Politics is a human behavior which varies from individual to individual and from group to group based on culture and ethics. It aims to achieve an interest or avoid a risk. Here, achieving interests depend on the rules of any competitive game rather than ethic. Human as a social being is seeking his interest beginning from his necessity to the rest of his desires.

So, what are the prominent political forms of the human political representation? Consequently, human could represent themselves as individual through group and state as:

\section{- $\quad$ Individual with these Features}

O Self-interest

- Avoiding risk more than achieving interest

- Religious or ethical influence and law abidance

O Pressing power by the riot

- $\quad$ Group with these Features

- Self-sacrifice

$\circ \quad$ Achieving interest more than avoiding risk

- Cultural influence

- Pressing power by civil disobedience

- $\quad$ State with these Features

- General interest in addition to the conflicts of interest quality

- Control

$\circ \quad$ Legislator 
- Pressing power by the military

History plays an important role in understanding political decisions over a certain period of time. History, despite the falsity it may contain, is the laboratory of politics. It provides a passage of time for events resulting from decisions that have led to many results. This result is used to compare decisions that have not yet been taken or are still in the making. This is in addition to mathematic technique used as game theory. So, history cannot repeat itself, but the history trial can be repeated if it has its conditions. The behavior of man to communicate gave him an experience that tells him what is right, what is inappropriate, what is diplomacy, intelligence, and courtesy of "some salt, so to speak". Political behavior can also produce a kind of violence as a means of change. This is what disturbance or war does. War is a form of creation and is the largest consumer in history. Most historical wars had created a new kind of power and ideas despite the scale of destruction and the numbers of death. Unlawful historical wars did not occur as a reaction and it often ended in failure. In war case negotiations, there is no freedom of territory until there is a freedom of decision especially.

What is the human criterion for using ' political concept in dealing with human? How can he formulate that attempt to persuade? What words and methods should he use? Should he use truth or deceit? What is the target? Is it a selfish target? Has there been a common gain? If there are common gains, will these gains cause harm to others? And how is the objective legitimate? Thus, all these questions tell how politics is varying.

Is the end justifying the means? This sentence is true if the war was a reaction for a war, not as an act for war, or when the end does not justify the means. This is because the end does not justify the crime. Subsequently, this is also true if the law is able to achieve justice because sedition is tougher than murder (Abdulaziz Jughaiman, 2019).

There is no justification for what can result to harm, if the law could prevent it. The Holy Quran calls for more moderate and realistic concept of war and provided a political solution over the military solution. [2.190] Fight in the way of allah those who fight against you, but do not aggress. Allah does not love the aggressors. [8.61] If they incline to peace, incline to it also, and put your trust in allah. Surely, he is the hearing, the knowing.[49.9] If two parties of believers fight, reform between them. If either of them is insolent against the other, fight the insolent one till they revert to the order of allah. If they revert, reform between them with justice, and weigh with justice. Allah loves those who weigh with justice. [60.8] Allah does not forbid you to be kind and to act justly to those who have neither made war on your Religion nor expelled you from your homes. Allah loves the just. [60.9] But Allah only forbids you to be guided by those who have fought against you in your religion's cause and expelled you from your homes or have supported others 
in your expulsion (Grand Shaykh, Hasan Qaribullah Shaykh, \& Ahmad Darwish, 2009). The difference between diplomacy and lying is a fine thread. This shows the extent of acceptance for what the politician offers and the extent of rejection by the spectators. The Holy Quran urges the use of soft words in trying to persuade someone-Softness, euphemistic and goodwill to gain enemy affection (Positiveness), as a political concept. [41.34] Good and evil deeds are not equal. Repel with that which is most just, and see, the one whom there is enmity between you will be as if he were a loyal guide (Grand Shaykh et al., 2009). On the other hand, it rejects the hypocrisy which is a concept worse than the concept of lying. Also, it is similar to the concept of treachery. So, the hypocrisy is a depletion of trust and good.

Politics is a social means practiced by all members of society. The only difference in what might be called political behavior and non-political behavior is the result of that behavior. So, they either merge or move away, and they get interests without respect to the ethical standards or losing of the interests in respect of ethical standards. So, who is responsible for the political behavior? Society or authority? What is the best model for formulating the nature of the policy? Is it the policy of the jungle? This produces only a spiritual deformation of human, to behave only by the superiority based on the capabilities of animal sense and intuition of what can provide a meal!

\section{Discussion}

Is it human path or choice?

Suppose there are two people participating in a bet. Both seek the gain, and both chose based on the probability of gain. On the other hand, the other persons who chose to be withheld from participating chose based on the probability of loss. At same time, they lose the potential chance of gain: "a game with two players, where a gain of one player equals a loss to the other, known as two-person zero-sum game" (Hamdy, 1987).

None of the people has the ability to make that gain inevitable. Therefore, man chooses but does not have absolute knowledge or absolute ability. Here, there is an existence of justice among human beings. So, any action is a selection; selection is a decision; and decision is a responsibility.

This responsibility is based on the knowledge under the circumstances in which the decision is taken, while the objectives that lead to decisionmaking is based on an expected outcome. Also, human as a non-eternity and an egoism being has infinite desires.

As a result, responsibility is the result of finite. The laws that the sun, earth, and moon follow is that they determine night and day, not humans. On the other hand, a human who possesses absolute power with absolute knowledge will not be responsible. 
Therefore, human responsibility is not the result of absolute power or absolute knowledge. As a result of this, the role of ethics and the role of faith stood out.

Here, augury or palmistry which is a kind of magic in some backward community is considered as unideological behavior that practices perversion by science trick (some of the laboratory waste if it is true). It aims to read body indication as body language reading, to send some true words with some wrong words into the unconsciousness of the victim for individual target or political target. It uses the logic of illogic to send an inevitable pre-result. A man's memory reminds him about what he did and what he will do. At the same time, a man's memory may be specious if he listens to a story from another man as this depends on his ear to imagine what he cannot see. In reality, we are only imagining the thing we cannot see (as a kind of deceiving the senses). This kind of juggling, sometimes, achieves results as any kind of vandalism or killing. This is like a complete crime because demolition is not like construction. [20.66] Moses replied: 'No, you throw first.' And by their sorcery it seemed to him that their ropes and staffs were sliding (Grand Shaykh et al., 2009).

Thus, the Holy Quran is used for untying most of this magic, especially that which contains illogic words known to be complex. This explains the importance of language as knowledge and as result.

Islamic society, despite all its principles, could not totally get rid of all immoral behaviors such as; suspicion, back bite, gossip, lie, deceit, hypocrisy, mockery, and envy. [49.11] Believers, do not let people mock other people who may be better than themselves. Do not let women mock women, who may be better than themselves. Do not find fault with one another, nor abuse one another with nicknames. An evil name is disobedience after belief. Those who do not repent are the harm doers. [49.12] Believers, abstain from most suspicion, some suspicion is a sin. Neither spy nor backbite one another. Would any of you like to eat the flesh of his dead brother? Surely, you would loathe it. Fear Allah, without doubt Allah turns (in mercy) and he is the merciful (Grand Shaykh et al., 2009). It aims to reach an ideal political and social model. Also, Islam calls for the righteousness of parents, relatives, and even neighbors with the attribute of mercy. This is because parents are the second reason of entity and the main reason for the relatives. A social feature aims at family and community cohesion. Since life blooms when a man loves a woman, Islam enacted marriage which is an absolute attribute between man and woman within the framework aim to achieve love within the contract that guarantees the right of women and children (Abdulaziz Jughaiman, 2019). Here, the possibility of divorce is regarded as the last resort to an impossible wedlock life. Therefore, if love is a possession and cult, the friendship is a choice and is unrestrained. 
Islam urges for peace. Based on its directive, it urges the use of the right hand in favorite activities as a rule through cultures and to use the right hand in handshake. Thus, this signifies peace in being in good terms and in establishing relationships. Therefore, any connection between two people or more is described as a community. Family is a community, workplace is a community, and market is a community. This gave rise to different laws that governs any society through different objectives, relationship, age level, and frequency. Therefore, there is an overlap between sociology and politics by using each other.

Furthermore, there is what is called transactions in Islam, which are the ethics through which people deal with one another. These transactions are the real representative of law. It depends on many themes beside the factor of civilization and science development. These themes should be allied to achieve the equation of the successful transaction. The right is derived from the truth, which is based on the ethics. Consequently, they include the following themes: right, truth, and ethic. For example;

The truth is " $\mathrm{A}$ " owns money.

The right is " $\mathrm{B}$ " does not steal " $\mathrm{A}$ 's" money.

The ethics will prevent " $\mathrm{B}$ " from stealing "A's" money.

The truth is Temperature of the earth is Compatible.

The right is Humans should not cause global warming by "pollution".

The ethics will prevent human from causing a global warming.

Furthermore, creation of the heavens and the earth survival is based upon the truth. [16.3] He created the heavens and the earth with truth (Grand Shaykh et al., 2009). So if injustice is oblong, the justice is a spherical. As the orbit, plant and the rain drop, it allows light to pass into a straight lines everywhere. Since human is the designate and responsible being among the creatures, human must not relinquish his place among the creatures. Human existence depends on the protection of human rights, the protection of animal rights, and the environment which in turn support human survival. Consequently, the ethics fundamental issue is "related to the issue of good, and the position of the human and his behavior. But the goal of ethics is to believe, in systematic fundamental mode, what is mental and what is equitable in behavior and in life (common). Principles of ethics and its fundamental must straighten without reference to foreign authorities or to righteous traditions in general or mentally acceptable. Therefore, the ethics must take a criticism and sublime position against prevalent politeness, while obligation of searching beyond the ethics is the query of what are hidden beyond the linguistic forms and what are hidden beyond the function of ethical words" (Peter Kunzmann et al., 1991). 
Since god was the one who gave man the right of choice, the worldly life was not exclusively for Muslims or for non-Muslims. Everyone has the right to life, choose, judgment, and influence. Also, not all non-Muslim were unbeliever and not all Muslim were believer because belief is the ratify of the right. Additionally, disbelief is the denial of the right. So, the presence of ethics is prior and synchronous with the presence of human, and any abandonment of ethics is beginning to produce the need for these ethics in order not to overcome evil balance over the balance of good.

The conjugation of ethics with wisdom in religion is also the same conjugation of wisdom with science as physicians are called wises in different cultures. However, this is because the treatment of any patient must have ethics to get rid of the disease. As such, there is no place for corruption.

The obvious difference between humans and other living organisms is that the other organisms play a specific role in nature instinctively. This role is relating to food chain that adapt to the laws of nature, and nature in turn adapts to it. To achieve ecological balance, it satisfied human needs. This depends on human choice as being able to think, learn, and work not only for the mating, but in order to further knowledge and discovery in regard to more choices and more freedom. This, therefore, will help to determine the differential destiny through his differential decisions between good and devilish. The philosophy of good and devilish emanate from human survival condition and its justification, not from his absolute desire. As in some organisms, thorns surround the wild roses to protect it against some threat or the bee biting against some threat. Also, there is a symbiosis life between Scorpion and one of the wild UROMASTYX for the purpose of protection. Virtually all organisms have an adjective of evil against unjust consumption in order to provide the minimum condition for their survival. So, the struggle between good and devilish is the struggle between good and evil together against devilish. For humans, it is to keep acquisitions and not to rob the acquisitions of others.

Human is characterized by its potential to choose. Humans possesses the same physiological properties. So, if the worker learns from the sunrise to work during the day, the thief learns from the sunset to steal at night. As a result, evil will be one of human choices which make up different destiny, either good or devilish. Thus, what shows the human character? Before then, we must know the identity of the man among people. So, one is not defined by his religion, but by his language because language is the only mean of communication between humans. Here, "language philosophy treats the evolution, development, semantic, and the function of language. The linguistic analysis that emerged after Wittgenstein are divided into two directions: the ideal linguistic direction, which involves linguistic criticism and by finding the nominal formulations to create language on a high level of logical 
precision to match the requirements of the exact sciences. On the other hand, "the philosophy of the ordinary language" analyzes the language from the angle of research in its basic, daily use, and its semantic" (Peter Kunzmann et al., 1991).

Therefore, a man cannot live in a place in the world without speaking the prevailing language, and he can practice religion everywhere including his place of residence regardless of his language. So, if the language is local, the religion is universal. In addition, religion is a form of law or custom and knowledge. Therefore, a person can practice only one religion, but he can speak many languages. This means there is a need to have common religious factors to practice many religions values. Also, language is the result of that knowledge or any form of knowledge, and it is the denominator among any society. So, religion represents the human character.

\section{Discussion}

\section{What is tradition?}

This involves the act associated with the same person without harming the others. Also, it does not seize other rights or spoil the public sense. It varies from a tradition rank to the rank of worship. For example, clothing may represent worship or may represent tradition.

So, tradition is an act that arose because of the need. And after the need has ended, this act continues.

Therefore, human generally has a need, e.g., a psychological or social need, civil need, or warlike need. On the other hand, he has no need because the need has ended or there is primarily no need. Furthermore, this explains the traditions that are practiced by individuals or society without asking why. In addition, changing these traditions as well is dependent on the same question: why should it be changed or left? Also, what is the determination between worship and tradition?

The determination of what is worship and what is tradition depends on what could be practiced by society as a tradition, or as worship, such as the standard wear. Here, there is a form of controversy on the issue of what is duty and what is not duty within a society that believes in same religion. This, however, made the role of the law unclear. Here, a form of laws issued by the society also come into view. It refers to religious or social criticism that is considered by the community in regard to certain act or certain words which in turn prevent or interdict that words or act. For example, in some conservatives societies, women are prevented from driving car by compensating them with tenant driver even if it is considered as a form of luxury.

In addition, there is what is called in Islam promotion of virtue and prevention of vice. [3.110] You are the best nation ever to be brought forth for 
people you order honor and forbid dishonor, and you believe in Allah (Grand Shaykh et al., 2009). The nation here refers to Muslims, while people refers to all people, both Muslims and non-Muslims. Righteous (right) and unrighteous (wrong), however, can be defined in two ways:

(1) A comprehensive way where all agreed on the acts or words by people despite the difference in their religion and traditions as justice. (2) All disagreed act or word by people despite the difference in their religion and traditions as injustice. Consequently, there are specific ways which is dependent on time and place. It is what is known among people, and they had agreed to it as an acceptable act or word at a certain place or time. Alternatively, it is what is known among people, and they had agreed to it as an unacceptable act or word at a certain place or time. However, this is subjected to the communities disparity by adopting social values by each community and the explanations put forward by each community in regard to what is acceptable and what is not acceptable.

The hypothetical communities provided by social networking sites are means of communication for all members and classes of the society. It directly interacts and provides a parallel media. In addition, it produced a mixed effect in politics and society. It also represents an alternative to some of the literary and political salons that spread in the 20th century but in an unrestricted and unspecific manner.

In Figure 1, a briefly suggested explanation of society general form, its components, and the logical relationship of some of these components is shown. So, it is possible to know what a community can produce, but it is difficult to exercise control over it. It is possible to influence it, but it is difficult to always get the desired results. This is because many social phenomena are random. "Since they were social classes as a relatively closed clique, the extent of social discrimination is linked to the portability of social movement. Therefore, there are no social strata and there is no solidity because total transformation is not found in human societies. All grades related to intermediate positions are between total change and total rigidity. The most important social classes available in modern societies are the working class, the class of leaders, the middle class, and the rural class. Also, the distinction between the classes is not always clear. Differences may be vast between countries, but each group of social groups has common features. However, it is useful to devise these aspects in their basic features." (Pierre \& Joseph, 1989). 


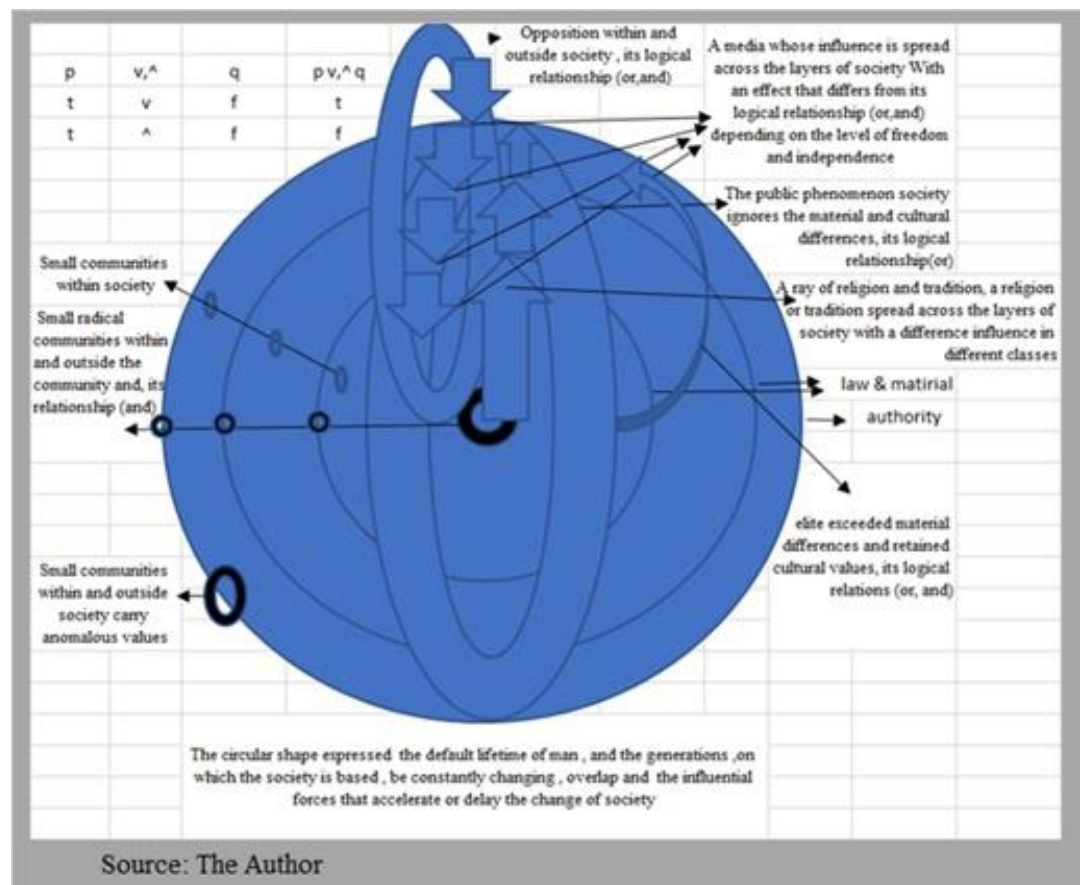

Figure 1. Society and some of its components and some logical relationships

Political and social situation is highly affected by the economic situation of any society. Therefore, sustenance has a close association with politics and society in Islam as a citizen or human rights. The sustenance in the Holy Quran takes two meanings: A special meaning and a general meaning. The special meaning is associated with the prophets and the goal is: - A miraculous aim that shows the ability of god and the importance of prophets.

- A hope which aims in giving hope to those who are in front of impossible circumstances.

- A general meaning of sustenance is about natural wealth. So, any country rich in natural resources already had its sustenance. That means all people of any country are to participate in these resources as their sustenance. [6.151] ...you shall be good to your parents, that you shall not kill your children because of poverty, we provide for you and for them (Grand Shaykh et al., 2009). So, god sustenance belongs to all people.

In other words, this verse "[17.70] We have honored the children of adam and carried them on both land and sea. We have provided them with good things and greatly preferred them above much of our creation (Grand Shaykh et al., 2009)" involves honouring human through the following:

- Transport through which man moves from place to place. This differentiated him from an animal and the law that he is subjected to. This is because animal quality is adapted with forced labor. This is aimed at avoiding 
any forced labor resulting from the lack of sea and land transportation. This is because the forced labor might cause harm and it might result to the loss of life. Therefore, honoring human is known as human rights.

- $\quad$ Sustenance with things that is good and pure. Since human was created from dust, then logically he will only live from what he was created from. So, the soil has been transformed from the soil to a taste that is good and pure.

- Above a great part of creation. [7.12] He (Allah) asked: 'What prevented you to prostrate, when I commanded you? ' 'I am better than he, ' he replied. 'You created me of fire and you created him of clay (Grand Shaykh et al., 2009). Here, fire is used by man for many needs. When, the devil - as his folly called him, which look like a flame when it ignites a fire- disobeyed god, he said with pride that he was created from fire, while Adam was made from clay. It was as if the fire honored Adam and prostrate to him despite the disobedience of the devil.

\section{Islamic Political System and Democracy}

Democracy allows the possibility of taking care of everyone's opinion, selection, and testing. Its success depends on the faith of others. It is also dependent on the moral obligation that believes in right more than in power. The success of democracy in developed countries was the result of that moral commitment. This in turn produced a kind of transparency as a test tool for that commitment and the level of corruption. Democracy is a restrictive idea by every nation separately, rather than an absolute idea over all nations. So, if the liberalism is the sky, then democracy is the geography. Since the government across history uses power rather than choice, its future will dependent on the level of moral obligation and choice rather than power. In addition, there are those who define democracy in ways that reflects its goals, such as socialist democracy. This seeks to achieve the socialism and communist goals of the state, which resulted from the power of revolution. "Popular democracy is a form of dictatorship of the proletariat." (Румянцева, 1985)

Upon the historical trial, there was a descriptive difference: The western democracy is where the state is serving the people, while the democracy of the socialist or communist is where the people are serving the state. Furthermore, there is a disparity between countries applying the last definition of democracy from the former Soviet Union to Cuba and China. China succeeded in attracting foreign capital and treated the world community more openly. Furthermore, China achieved high growth by focusing on the aims of economy rather than the aims of politics.

In Islam, allegiance is a choice and test. Prophet Mohammad was able to compel people by any means such as religion or power to declare himself 
as a governor. However, he preferred the allegiance as a form of democracy that represents legality.

In addition, it depends on the extent of democracy output in an Islamic society that must keep society faithful to Islam, which in turn keeps Islam existence and Islam legislation principle. However, the word "king" had many meanings in Islam such as:

- Judgement, knowing or wisdom, and governmental. Therefore, when god gave the ruling to the prophets, they did not explain that as the possession of wealth. As a result, they died without inheriting any material wealth. This is because the ruling is done on moral standards, then mental and bodily abilities. [2.247] Their prophet said to them: 'Allah has raised saul to be your king. ' But they replied: 'Should he be given the kingship over us, when we are more deserving of it than he and he has not been given abundant wealth? ' He said: 'Allah has chosen him over you and increased him with amplitude in knowledge and body. Allah gives his kingship to whom he will. Allah is the embracer, the knower (Grand Shaykh et al., 2009). Out of the criteria by which god chose prophets as a favor by god to nations, the most important is the fidelity on the resources of the nations and human rights.

- Government or the meaning of presidency depends historically on the power.

Islam comprised of two phases; First phase is the advisory and selection system after Prophet Mohammad, Omar, Othman, and Ali. Second phase is the monarchism system in Islam which is a result of power. All prophets and messenger represent the paragon. Not all prophets and messenger are kings, not all kings are prophets or messengers. Therefore, the choice of people will be conditioned by the people's belief and the ruler's belief. This, therefore, refers to the dilemma of the appropriateness of the people believing with the ruler believing. It is also subject to the constitutions derived from the principles of the Holy Quran and Sunnah (Abdulaziz Jughaiman, 2019). It entails the agreement of both sides based on the correct interpretation of the Holy Quran and Sunnah. So, the conditions of people submission are come into view. One of these dilemma secretions was the advent of groups and sectarians that adopted different interpretations due to the absence of party system. The party system is not a new idea, but it has emerged with human social development to represent a form of political organization that reflects the political map and expresses the economic, politics, and social problems in addition to its goals. This in turn plays a role in the identification of the party. It also carries a kind of support for the weak one or defeated one because it makes their dispersed and pursued voice to be heard and recognized. Furthermore, it forms a public opinion influence towards corruption issues and erroneous political decisions. In addition, it derives its existence from the 
people at all levels and from public opinion. The chaos created by the absence of parties is evident in the large numbers of political prisoners, secret opposition groups, emigrants, clear absence of freedom of opinion, and widespread corruption and ideologues. Party is not a kind of political division. This is because it reflects an acceptance and rejection based on common interests. In the absence of party where interests are not shared, this is described as a political division. So, this concludes that democracy (allegiance) in Islam serves Islam as existence and a legislation provenance that applied teachings of god depends on the correct interpretation of the teachings of god. Additionally, it is also used with another legislation provenance.

The routine Islam ignores the concept of the party and accepts the concept of the group. The party is built within a legal framework. It gives the opposition voice a legal status. In addition, it can attract a larger people of societies through the legal status which is based on its general character. It carries the general principles of the state. While the group does not have any legal framework, and its expression of the opposition is an ideological expression through propaganda and supplication, it does not always carry the general principles of the state. However, the category or the size of people that it may attracts still remains in an ideological framework rather than a scientific framework. This is what causes the overlap of politics within religious objectives away from the reality. The concept of party is not prohibited in Islam within the framework of the Islamic legislation. In addition, it remains prohibited in case the party carries ideas or goals hostile to Islam.

\section{Islam and Civilization}

The call of Islam to the community in mosques and religious events is an invitation to social solidarity. This is because it does not call for secular aims, but for religious and moral aims in addition to other forms of social solidarity such as the visiting of patient, attending funerals, and charity. On the other hand, Islam does not reject individual Muslim affiliations outside Muslim societies like Muslims living in non-Muslim countries. Their affiliations must be to the countries that they belong to and must also carry its nationality. This is because it depends primarily on laws related to transactions.

How can the civilization clash be diagnosed?

In this present age, the world is suffering from terrorism and so-called Nazism or extreme tendencies. Furthermore, these tendencies closely correspond to each other in many characteristics with logic relation $(A N D)$ :

Terrorism

- Violence

- $\quad$ Ignored geographical or national boundaries 
- $\quad$ Frames to chaotic, bigotry and religious or cultural wars

- $\quad$ Generalized the description

- $\quad$ Amputated society by doctrine or ideological racism

- $\quad$ Unclear, undetermined politics target

Nazism or Extreme Tendencies

- Violence

- $\quad$ Ignored geographical or national boundaries as The Nazi era (Second

World War)

- $\quad$ Ignored geographical boundaries

- $\quad$ Frames to a chaotic, bigotry and religious or cultural wars

- $\quad$ Generalized the description

- $\quad$ Amputated society by ethnic racism

- Unclear, undetermined politics target

Furthermore, one of the potential dangers can be seen from common attributes in different directions to drive a social category to be attracted by others. They both serve each other to reach the virtual world through which they succeed and polarize societies. Any national tendency which takes the concept of rights in its favor will develop the first ideas of war or the culture of war. This also applies to all forms of corruption. Therefore, there is an increase in national tendency in cases of war and territorial discords which is being used by extremist political tendencies. Therefore, the Holy Quran addressed such behavior: [5.8] Believers, be dutiful to allah and bearers of just witness. Do not allow your hatred for other people to turn you away from justice. Deal justly; it is nearer to piety. Have fear of allah; allah is aware of what you do (Grand Shaykh et al., 2009).

Subsequently, this means that there is no discrimination between rights holders regardless of their affiliations.

\section{Discussion}

How can we avoid the double standards in the subject of human rights on the level of nations?

Basically, there are two main sources of cultures; Prophets and Philosophers.

So, any attempts in trying to put these sources opposite to each other can make an extremism culture by generalization method.

The problem exists in the application if it cannot be accepted when applied. This is the case for both Islamic or secular models separately due to the prejudice of complete opposition between Islam and secular applications. Thus, it clashes with reality and with the minor understanding of both Islamic and scientific approaches. 
The problem is solved through access to that application of Islam and science together. This made us to understand the importance of the holiness of the prophets and the important of philosophers in the global culture formation process. In addition, it cannot change the quality of life they have been experienced in all its aspects or take full responsibility, especially political and social. This applies to all prophets and messengers. Furthermore, the criticism directed to the prophets is a kind of generalization, and it lacks scientific logic for these reasons:

- $\quad$ Their absence and their inability to receive, accept, or reject criticism. - $\quad$ The breadth of the social class that sanctifies them all over the world.

- $\quad$ These classes are subject to different political and social systems from country to country.

- $\quad$ Faith in prophets is not a belief in scientific facts that can be criticized but is a part of human emotional instinct for religion.

- $\quad$ Such criticism is a kind of criticism to what can be loved, including individual emotions, faith, and the right of human to love.

- $\quad$ Such criticism can lead to a change in the definition of society members by religious definition, by sectarianism, rather than the definition of society member that speaks common languages and holds one nationality. Thus, this in turn results in society disintegration.

- It is difficult to combine two societies of two different countries, which is an Islamic society of one country with a non-Islamic society of another country. This is because each society derives its strength through the legislative and executive power that pressures as a pressure group. "The prosperity of pressure groups reflects accurately the socio-economic structures and the ideological conflicts in the concerned country. In this description, there are significant differences between a country and another" (Jean \& Bahij, 1983). An example is the inclusion of Turkey with the Muslim community into the European Union. European legislation has guaranteed rights for Muslims, while Turkish legislation guaranteed the rights of non-Muslims. The legislative and executive authority of both societies cannot offer this as one country. They can only endure this in two separate communities. Thus, this is because they derive their strengths from their separate societies rather than as a single society. In addition, the society itself evolves throughout history within the basic culture of the society and its beliefs. Whenever there is liberation of any society, there is a social force that is the source of the legislative and executive powers. This force cannot come from outside except in the case of colonialism. Any society or bloc can overcome any social problem if that problem is part of it. On the other hand, it may face a coup when these problems originate from abroad or result from economic imbalance or depletion war. This is because it forcibly changes many of the 
logical relations on which the society is based upon. Here is one of the game theory applications between Turkey and the European Union in main issues and also between UK and European Union in the UK exit negotiations.

What is a politic and what is a religion?

"The philosophy of religion is the study of religion in its essence. This can be achieved by studying religion function between humans and religion function in the society. Also, it provides, "if necessary", a criticism for all of this" (Peter Kunzmann et al., 1991). Initially, this paper defines religion 'lingually' as follows; 'religion is what human is indebted to humans and environment of rights, despite of the difference in religions, which in turn means humans are indebted to god because faith in god supports humans' rights and environmental rights."

Worship in Islam was taken from its form and content, "typical" or codified. This does not accept a decrease or an increase because it does not change the common rights. Thus, this do not foster religious sectarian. This sectarian ignores ones rights, tears people apart, and it interpolates worship into politics. When secularism aims to avoid the fever and clashes of religious sectarian, Islam can be used to achieve this goal by employing corporate factors to determine the laws that can be accepted and what can be rejected. So, any antagonism by religion (as merely worship) will lead to clashing between civilizations. As a result, worship is not an affiliation. At same time, worship evokes the relation with god which should edify character to transactions in all life affairs.

Mosques are the places of worship in Islam. It plays an important role in the political and cultural orientation of society through selection of the verses that are read during prayers. Therefore, this may cause unwitting guidance to Islamic societies within certain verses as the prayers do not correlate other than those verses. Also, that may cause an ideological interpretation. Despite that, it is not required in Islam. Therefore, the required reading should start from the beginning of the Holy Quran to its end. [73.20] Recite from it as much as is easy (Grand Shaykh et al., 2009). This should be done as much as it may be easy, in regard to how many verses or quantitative selection, and not as a specific selection.

In addition, believing in the Holy Quran means believing in all Holy Quran's verses, and not believing in some and forgetting the rest. However, this behavior leads to a misinterpretation of Islam because the Prophet Muhammad has died, and the descent of the Holy Quran is complete. This event may be unfavorable and the selection of that verse at another time for a reason does not exist in the current time and place, thereby leading to misinterpretation. This is attributed to the fact that the prayer cannot realize the full Holy Quran in his consciousness when listening to the selected verses. 
Therefore, this provides an explanation of everything that the listener may receive and deal with, especially with the repetition in politics and society. This in turn eliminates the condition (Canceling If), generalizes the result, and selects an illogical decision. So, the reading of the Holy Quran from beginning to its end, not through the selection between the verses, urges to think again.

In addition, the affiliation by worship leads to polytheism. Polytheism is a form of political corruption as the worship in Islam does not support anyone to obtain the right of other persons. Also, there is no distinction between human beings. However, polytheism was the only way to get out of this justice and achieve illegal gains. The logic of non-polytheism is the logic of right, while the logic of polytheism is the logic of power. Polytheism is the assumption of another hidden power that is parallel to the power of god. Polytheism fosters the formulation laws in accordance to the desire of some classes. It aims to get rid of the theory of equality between human rights to achieve political or illegal material gains at the expense of the right of others. This combines believing with unbelieving. Also, the polytheist believes in the level of refusal to comply with laws that do not agree with its interests. Polytheist is a form of fear of justice-justice that was sent by the prophets who did not inherit money, governmental, personal or category. Here, the migration of some early Muslims to Abyssinia (Ethiopia) occurred. They escaped from injustice and harm as a kind of political asylum which gives importance to the value of rights, justice, and distinction.

The religion of Islam consists of the testimony that there is no god but allah, and that Mohamad is a prophet and messenger of Allah. Therefore, Islam has steady principles used to identify the Muslim. At the same time, Muslim as a changeable human does not identify Islam. On the other hand, the testimony means that everyone knows Islam through Prophet Mohamad or by the Holy Quran, and they must testify in order to be accepted in Islam. Therefore, who has been accepted in Islam as a Muslim cannot leave Islam because his testimony will be a false testimony.

[2.256] There is no compulsion in religion. Righteousness is now distinct from error. He who disbelieves in the idol and believes in allah has grasped the firmest tie that will never break. Allah is hearing, knowing (Grand Shaykh et al., 2009). While entry to Islam is optional, getting out of Islam is not optional. This is because:

- Islam recognizes all religions in its texts. It is the last of the heavenly religions. His prophet is the last of the prophets, and it recognizes all the prophets. [33.40] Muhammad is not the father of any of your men. He is the Messenger of Allah and the seal of the Prophets. Allah has knowledge of all things (Grand Shaykh et al., 2009).

- $\quad$ Getting out of Islam is a kind of non-recognition of Islam. [3.85] He who chooses a religion other than Islam, it will not be accepted from him, and 
in the everlasting life he will be among the losers (Grand Shaykh et al., 2009). In addition, a false testimony means all Islamic agreements will be false, especially personal status. So, if the right to choose Islam is the right of human beings, then the refusal to leave Islam is the right of Islam, the right of recognition or the right of entity, and the right of legislation.

\section{Conclusion}

This paper concluded that human responsibility is not the result of absolute power or knowledge. Therefore, the role of ethics and the role of faith stood out. The presence of ethics is prior and synchronous with the presence of human. Also, any abandonment of ethics is beginning to produce the need for these ethics. So, this concept is consistent with freedom and it denies the concept of tyranny in Islam. Transactions are the ethics whereby people deal with each other in order to achieve the equation of a successful transaction. The right is derived from the truth, which is based on the ethics. Consequently, they include the following themes: right, truth, and ethic. Also, the Holy Quran calls for more moderate and realistic concept of war and it provides a political solution over the military solution which urges to use soft words in persuasion (softness), euphemistic, and goodwill to gain an enemy affection (Positiveness), as a political concept. So, the sentence ends with justifying the means? Is it true that the war was a reaction for a war, not an act for a war, or the end does not justify the means? In addition, the Holy Quran supports honouring human by means of transportation and good things. This is because the forced labor might cause harm and might result to the loss of life. Therefore, honoring human is regarded as human rights. Also, the Holy Quran is against discrimination between rights holders regardless of their affiliations. So, all these explanations are enhancing the principle of human right.

This paper concluded that a promotion of virtue and prevention of vice which Islam called for can be defined in two ways: in a comprehensive and in a specific way. Also, the determination of what is worship and what is tradition depends on what could be practiced by society. Here, there is a form of controversy on the issue of what is duty and what is not duty within a society that believes in same religion. This, however, made the role of the law unclear. Here, a form of laws issued by the society also come into view i.e., the use of religious or social criticism that is considered by the community towards certain act or certain words which in turn prevent or interdict that words or act. Also, this paper defined tradition as an act that arose because of the need. After the need has ended, this act continues. These definitions present a better understanding of the society behavior, the role of orientation, and how to be in the right direction.

This paper concluded that the democracy (allegiance) in Islam serves Islam's existence and a legislation provenance that applied the teachings about 
god. This is based on the choice of people that are conditioned by the people believing and the ruler believing. This, therefore, refers to the dilemma of the appropriateness of the people believing with the ruler believing. It is also subject to the constitutions derived from the principles of the Holy Quran and Sunnah. It entails the agreement of both sides based on the correct interpretation of the holy Quran and Sunnah. Also, this paper concluded that entry to Islam is optional, while getting out of Islam is not optional. This is because Islam recognizes all religions in its texts. Also, it is because getting out of Islam is a kind of non-recognition of Islam. In addition, a false testimony means all Islamic agreements will is false, especially personal status. So, if the right to choose Islam is the right of human beings, then the refusal to leave Islam is the right of Islam, the right of recognition or the right of entity, and the right of legislation. In addition, it is difficult to combine two societies of two different countries e.g., an Islamic society of one country with a non-Islamic society of another country. However, this is because each society derives its strength through the legislative and executive power from their societies separately rather than as a single society. Also, this paper concluded that any antagonism by religion (as merely worship) will lead to clashing between civilizations. As a result, worship is not an affiliation. In addition, the affiliation by worship leads to polytheism which is a form of political corruption. Also, Islam has steady principles that identify Muslim. At the same time, Muslim as a changeable human does not identifies Islam. Also, identity is not defined by religion, but by language. On the other hand, religion represents human character. These concepts enhance individuals' belonging to their homeland despite their religion and, at the same time, it helps to integrate them into their communities.

\section{References:}

1. Ahmad Darwish (2009). The Holy Quran translated by: Grand Shaykh, Professor Hasan QARIBULLAH Shaykh: verses [51.56],[3.110] [16.3] [12.2] [61.6] [60.9] [2.31] [73.20] [36.40] [21.30] [27.88] $[20.114][22.73] \quad[17.37] \quad[16.5] \quad[16.6] \quad[17.85]$ http://www.equran.com/language/english/english4/default.html

2. Abdulaziz Jughaiman (2019). European Scientific Journal, 16, 18,25, 15-37.

3. Amartya Sen \& Shaagy Jalal (2004). Development as freedom $\left(1^{\text {nd }}\right.$ ED). Politics press, Kuwait.

4. Ebraham Dusogy Abadah \& Abdulaziz Al-Ghnaam (2005). History of political thought $\left(1^{\text {nd }}\right.$ ED). DAR BYBLION, Paris.

5. Eric Rasmussen (1994), games and information ( $\left.2^{\text {nd }} E D\right)$. Blackwell Cambridge MA \& oxford UK. 
6. Frits Steppat \& Abdulghfaar Makaawe (2004). Islam ALS Partner $\left(1^{\text {nd }}\right.$ ED). Politics press, Kuwait.

7. Gertrude Himmelfarb \& Mahmood Ahmad (2009). The roads to modernity, the British, French, and American enlightenment ( $\left.{ }^{\text {nd }} E D\right)$. National Council for Culture, Arts and Letters, Kuwait.

8. Hamdy Taha, A. (1987). Operations Research (4 ${ }^{\text {th }}$ ED). MACMILLAN Publishing Company. New York. Chapter (11.4).

9. Jean Meynaud \& Bahij Shaaban (1983). Les Groupes De Pression.( $3^{\text {rd }}$ ED). EDITIONS OUEIDAT Publications \& presses Universitaires de France, Beirut \& Paris. Unit (1).

10. Karl Popper \& Mohhamad Al-Baghdade (2006). Logic of scientific research $\left(1^{\text {nd }}\right.$ ED). AL-MONATHAMAH AL-ARABIA LEATRRJAMAH. Beirut.

11. Mohammed Al-Fendy (1984). Principles of mathematical logic $\left(1^{\text {nd }}\right.$ ED). DAR AL-NAHDAH AL-ARABIA, Beirut.

12. Mohammed Mahmoud Rabea \& Ismaeel Sabree Mogled (1993/1994), Encyclopedia of political science ( ${ }^{\text {nd }}$ ED). University of Kuwait, Kuwait.

13. Mohammed Sbeala \& Abdulsalam Bin-Abdulale (2001). Human right basis and philosophical fundamental $\left(2^{\text {nd }} E D\right)$. DAR TOBGAL press, Casablanca.

14. Peter Kunzmann, Franz-Peter Burkard, Franz Wiedmann, Axel Weib, \& George Katorah (1991). DTV-Atlas Philosophie. ( $8^{\mathrm{TH}}$ ED.). East Library, Beirut: Units (6).

15. Philip Taylor \& Same Khashabah (2000). Munitions of the mind, war propaganda from the ancient to the nuclear age $\left(1^{\text {nd }} E D\right)$. National Council for Culture, Arts and Letters, Kuwait.

16. Pierre Laroque \& Joseph Kebbe (1989). Les classes sociales ( $\left.2^{\text {nd }} E D\right)$. EDITIONS OUEIDAT Publications \& presses Universitaires de France, Beirut \& Paris. Units (1), Units (2).

17. Румянцева A.M. \& Dar Al-Taguddum (1985). НАУЧНЫЙ КОММУНИЗМ. Progress Publishers, Moscow. Unit(D).

18. Toby E. Huff \& Mohammad Asfoor (2000). The rise of modern science Islam, china, and the west $\left(2^{\text {nd }} E D\right)$. National Council for Culture, Arts and Letters, Kuwait.

19. Willard Quine (1996). Elementary logic (1 ${ }^{\text {nd }}$ ED). DAR ALTALYAAH Publications \& presses, Beirut. 